\title{
REVIEW
}

\section{The role of public health dietary messages and guidelines in tackling overweight and obesity issues}

\author{
Yi Yi Lee ${ }^{1,5^{*}}$, David Tan ${ }^{1}$, José Siri' ${ }^{1}$, Barry Newel1 ${ }^{2}$, Yi Gong ${ }^{3}$, Katrina Proust ${ }^{2}$ \& \\ Terry Marsden ${ }^{4}$
}

${ }^{1}$ United Nations University International Institute for Global Health (UNU-IIGH), Kuala Lumpur, Malaysia; ${ }^{2}$ Fenner School of Environment \& Society, The Australian National University, Canberra, ACT, Australia; ${ }^{3}$ Sustainable Places Research Institute \& School of Medicine, Cardiff University, Cardiff, United Kingdom; ${ }^{4}$ Sustainable Places Research Institute \& School of Geography and Planning, Cardiff University, Cardiff, United Kingdom, ${ }^{\mathbf{5}}$ Division of Nutrition \& Dietetics, International Medical University, Kuala Lumpur, Malaysia

\begin{abstract}
Overweight and obesity in Malaysia pose serious threats to health. Prevalence has escalated to alarming levels in recent decades despite a multitude of public health dietary messages geared towards obesity prevention and health promotion. Gaps between health messages, messengers, and the public must be identified and closed to effectively combat obesity and overweight. This review article aims to examine public health dietary messages, guidelines, and programmes for the prevention of obesity in Malaysia, and explore potential reasons for the continued rise in its prevalence. Public health dietary communication in Malaysia has progressed and improved substantially over the years. However, most messages have been designed for the general audience, with little consideration of differences in physical, social, cultural, and environmental backgrounds, and varying levels of comprehension. We offer several recommendations to increase the effectiveness of public health dietary messages in fighting the obesity epidemic, based on a cross-sectoral, place-based approach that recognise the complexity of the underlying causes of obesity.
\end{abstract}

Keywords: Public health dietary messaging; obesity; Malaysia; place-based approach; cross-sectoral approaches

\section{INTRODUCTION}

Obesity has tripled worldwide since 1975, reaching epidemic proportions in both developing and developed countries; as of $2018,13 \%$ of adults are obese and $39 \%$ overweight (WHO, 2018). Meanwhile, the prevalence of overweight and obesity among children and adolescents have risen from 4\% in 1975 to $18 \%$ in 2016 (WHO, 2018). The Global Burden of
Disease Study (Ng et al., 2014) reported a prevalence of overweight and obesity in Southeast Asia as $22.1 \%$ among men and $28.3 \%$ among women, with the highest rates in Malaysia at $48.3 \%$ and $48.6 \%$ for men and women, respectively. The 2015 Malaysian National Health and Morbidity Survey (NHMS) reported similar numbers, estimating the national prevalence of overweight and obesity in

\footnotetext{
*Corresponding author: Dr. Yi Yi Lee

Division of Nutrition \& Dietetics, School of Health Sciences, International Medical University

No. 126, Jln Jalil Perkasa 19, Bukit Jalil, 57000 Kuala Lumpur, Malaysia

Tel: +603 8656 7228; E-mail: yiyilee@imu.edu.my/leeyy.yiyi@gmail.com

doi: https://doi.org/10.31246/mjn-2019-0084
} 
adults at $30.0 \%$ and $17.7 \%$, respectively, for a total of $47.7 \%$ (IPH, 2015). In just two decades, the prevalence of overweight adults has doubled from $16.6 \%$, while obesity has increased four folds from 4.4\% (IPH, 1996). Malaysia has stated its intent to stop the rise in the prevalence of obesity by $2025(\mathrm{MOH}$ Malaysia, 2016). The US\$1-2 billion (RM4.26- 8.53 billion) spent to combat obesity in 2016, including direct and indirect costs, is equivalent to $~ 10-19 \%$ of the national healthcare expenditures (ARoFIIN, 2016). Public health messages around nutrition such as those issued by the Ministry of Health $(\mathrm{MOH})$ are important as one of the range of efforts for health promotion and obesity. Yet, despite all these actions, obesity rates have continued to rise sharply.

Failure to halt the dramatic increase in the prevalence of overweight and obesity in Malaysia and worldwide has contributed to increased health risks for non-communicable diseases (NCDs) such as diabetes, cardiovascular diseases and cancers, as well as other health issues, consequently leading to higher morbidity and mortality rates. About $8 \%$ of total mortality each year is attributed by obesity (Beaglehole et al., 2011). Beyond increased risk of obesity-related chronic diseases and poorer quality of life, the healthcare costs of treating obesity-related disease conditions are rapidly escalating. On average, obese Malaysian males and females lose about 6-11 years and 7-12 years of their productive life, respectively (ARoFIIN, 2016).

This paper reviews some of the public health dietary messages, guidelines, and programmes related to overweight and obesity in Malaysia. It identifies possible reasons for the continuing increase in its prevalence in the face of abundant public health messages and offers recommendations for a more systemic, place-based approach to slowing and reversing the rise in obesity.

\section{Public health dietary messages}

Public health messages related to nutrition and obesity in Malaysia

In recent decades, the Malaysia $\mathrm{MOH}$ has disseminated numerous public health messages, various sets of nutritional and dietary guidelines, and a series of programmes for the public and for health professionals. The National Plan of Action for Nutrition of Malaysia (NPANM) underlies Malaysia's strategy for addressing public health nutrition, and to date, three versions of the plan have been published since 1996 (NCCFN, 1996; NCCFN, 2006; NCCFN, 2016).

Table 1 compares the evolving aims of the three NPANMs and the evolution of the main areas of focus and facilitating strategies. In the 1996-2000 version, most NPANM targets and goals were to address nutritional deficiencies, with no set target for overweight and obesity. At that time, the prevalence of overweight and obesity were $16.6 \%$ and $4.4 \%$, respectively (IPH, 1996). By 2003, these have increased to $26.7 \%$ and $12.2 \%$, representing nearly two- and threefold increases, respectively, in over just seven years (Azmi et al., 2009). By the launch of the second NPANM in 2006, the national prevalence of overweight and obesity among adults were reported at $29.1 \%$ and $14.1 \%$ (IPH, 2006), with the prevalence of NCDs also on the rise. The new plan, shifted to meet the new needs accordingly, aimed to enhance the nutritional status of the entire population and also to prevent and control diet-related NCDs. NPANM II sets a population-level goal of not $>30 \%$ overweight and not $>15 \%$ obesity, of which these targets were not achieved. In view of the current critical situation, the third and most recent NPANM (2016-2025) has adopted a goal of no further increase in any obesity-related indicators, taking NHMS 2015 data as a baseline. It has also established new indicators, such as abdominal obesity for overweight and obesity among adults $>60$ years of age. 
Table 1. Aims of the NPANM I, II, and II (1996-2000, 2006-2015, 2016-2025) and the evolution of the main areas of focus and facilitating strategies

\begin{tabular}{|c|c|c|c|}
\hline Main objectives & $\begin{array}{c}\text { National Plan of Action } \\
\text { for Nutrition of Malaysia } \\
(1996-2000) \\
\text { [NPANM I] }\end{array}$ & $\begin{array}{c}\text { National Plan of Action } \\
\text { for Nutrition of Malaysia } \\
\text { II (2006 -2015) } \\
\text { [NPANM II] }\end{array}$ & $\begin{array}{c}\text { National Plan of Action } \\
\text { for Nutrition of Malaysia } \\
\text { III (2016-2025) } \\
\text { [NPANM III] }\end{array}$ \\
\hline & $\begin{array}{l}\text { Designed to ensure } \\
\text { optimal nutritional } \\
\text { status of the } \\
\text { population for human } \\
\text { resource development } \\
\text { towards the countries } \\
\text { industrialisation } \\
\text { process and } \\
\text { development of a } \\
\text { caring society by the } \\
\text { year } 2020 \\
\text { Addresses both under } \\
\text { and overnutrition } \\
\text { Nutrition targets } \\
\text { and goals were } \\
\text { mainly for child } \\
\text { survival, protection, } \\
\text { and development: } \\
\text { malnutrition, anemia, } \\
\text { iodine deficiencies, } \\
\text { etc. }\end{array}$ & $\begin{array}{l}\text { Designed to achieve } \\
\text { and maintain optimal } \\
\text { nutritional well-being } \\
\text { of Malaysians } \\
\text { - Addresses current } \\
\text { and emerging issues } \\
\text { in nutrition at } \\
\text { that point of time } \\
\text { where Malaysia is } \\
\text { confronted with } \\
\text { the problem of } \\
\text { dual burden of } \\
\text { malnutrition - } \\
\text { underweight and } \\
\text { overweight and } \\
\text { obesity }\end{array}$ & $\begin{array}{l}\text { Designed to address } \\
\text { food and nutrition } \\
\text { challenges in the } \\
\text { country } \\
\text { - Identified } 46 \text { nutrition } \\
\text { indicators and set } \\
\text { targets to be achieved } \\
\text { by } 2025 \\
\text { - Aims to strengthen } \\
\text { food and nutrition } \\
\text { security, enhance } \\
\text { nutritional status, } \\
\text { and reduce diet- } \\
\text { related NCDs }\end{array}$ \\
\hline
\end{tabular}

\begin{tabular}{|c|c|c|c|}
\hline $\begin{array}{l}\text { No change/ } \\
\text { Maintained }\end{array}$ & Removed after NPANM I & Added into NPANM II & Added into NPANM III \\
\hline $\begin{array}{l}\text { - incorporating } \\
\text { nutritional } \\
\text { objectives into } \\
\text { development } \\
\text { policies and } \\
\text { programmes } \\
\text { - improving } \\
\text { household food } \\
\text { insecurity } \\
\text { - food quality and } \\
\text { safety } \\
\text { breastfeeding } \\
\text { - preventing and } \\
\text { controlling specific } \\
\text { micronutrient } \\
\text { deficiencies } \\
\text { promoting } \\
\text { appropriate diets } \\
\text { and healthy } \\
\text { lifestyles } \\
\text { assessing, } \\
\text { analysing, and } \\
\text { monitoring } \\
\text { nutrition } \\
\text { situations } \\
\text { reducing } \\
\text { overweight and } \\
\text { obesity and other } \\
\text { diet-related NCDs }\end{array}$ & $\begin{array}{l}\text { - preventing and } \\
\text { managing infectious } \\
\text { diseases }\end{array}$ & $\begin{array}{l}\text { - complementary } \\
\text { feeding practices for } \\
\text { young children } \\
\text { strengthening } \\
\text { research and } \\
\text { development } \\
\text { - strengthening } \\
\text { institutional capacity } \\
\text { in nutrition activities } \\
\text { ensuring nutrition } \\
\text { and dietetics are } \\
\text { practised by trained } \\
\text { professionals }\end{array}$ & $\begin{array}{l}\text { - } \text { maternal nutrition } \\
\text { sustaining food } \\
\text { systems to promote } \\
\text { healthy diets } \\
\text { providing standard } \\
\text { nutrition guidelines } \\
\text { for various targeted } \\
\text { groups } \\
\text { strengthening } \\
\text { community capacity } \\
\text { in nutrition activities }\end{array}$ \\
\hline
\end{tabular}


Whilst all three plans have taken on such basic goals as ensuring food quality and safety, and promoting appropriate diets and healthy lifestyles, the focal areas and facilitating strategies for nutrition have evolved in successive NPANMs (Table 1). For example, NPANM I prioritised the prevention and management of infectious diseases, while NPANM II addressed complementary feeding for children and promoted institution-building strategies to strengthen research, development, and capacity. NPANM III recognises the importance of systemic action and local context, promoting multidisciplinary teamwork that builds capacities and empowers communities, the inclusion of food systems frameworks in nutritional strategies, and the development of targeted guidelines for vulnerable groups.

The Malaysian Dietary Guidelines are an important strand of public health messages related to nutrition. Aimed primarily at health care providers, they are "intended to act as a tool for healthy eating promotion towards achieving the NPANM" (NCCFN, 2010). Established in 1999 with eight key messages designed to prevent nutritional deficiencies and chronic diseases, the Guidelines were revised and updated in 2010, splitting several of the original messages to more specifically emphasised messages, for example, the importance of daily physical activity and fruit consumption, and adding on four new guidelines, making a total of fourteen key messages (Figure 1). These changes reflect a better understanding of the origins of obesity and lifestyle-related diseases in Malaysia.

Another strand of public health nutrition promotion encompasses the visually-oriented Malaysian Food Pyramid and Healthy Plate, both aimed at the general public. The Malaysian Food Pyramid, first introduced in 1997 (Tee, 2011), is modelled on the United States Department of Agriculture's

\section{Evolution of dietary guidelines in Malaysia \\ (Malaysia Dietary Guidelines 1999 and 2010)}

1. Eat a variety of foods within your recommended intake.

2. Maintain body weight in a healthy range.

3. Be physically active every day.

4. Eat adequate amount of rice, other cereal products (preferably whole grain) and tubers.

5. Eat plenty of fruits and vegetables every day.

6. Consume moderate amounts of fish, meat, poultry, egg, legumes and nuts.*

7. Consume adequate amounts of milk and milk products. *

8. Limit intake of foods high in fats and minimise fats and oils in food preparation.

9. Choose and prepare foods with less salt and sauces.

10. Consumes foods and beverages low in sugar.

11. Drink plenty of water daily.

12. Practise exclusive breastfeeding from birth until six months and continue to breastfeed until two years of age.

13. Consume safe and clean foods and beverages.*

14. Make effective use of nutrition information on food labels.*

*Key messages that were introduced in the Malaysia Dietary Guidelines 2010

Figure 1. Evolution of dietary guidelines in Malaysia

(USDA) Food Guide Pyramid (USDA, 1992). Intended as a visual guide to assist the public in planning suitable daily food consumption in terms of choices and quantities, the current version of the pyramid is contained in the Malaysian Dietary Guidelines 2010 (NCCFN, 2010). In 2016, the Malaysian Healthy Plate (provide reference), modelled on the USDA MyPlate (Table 2 ), was released to supplement and in some ways supersede the Food Pyramid. 


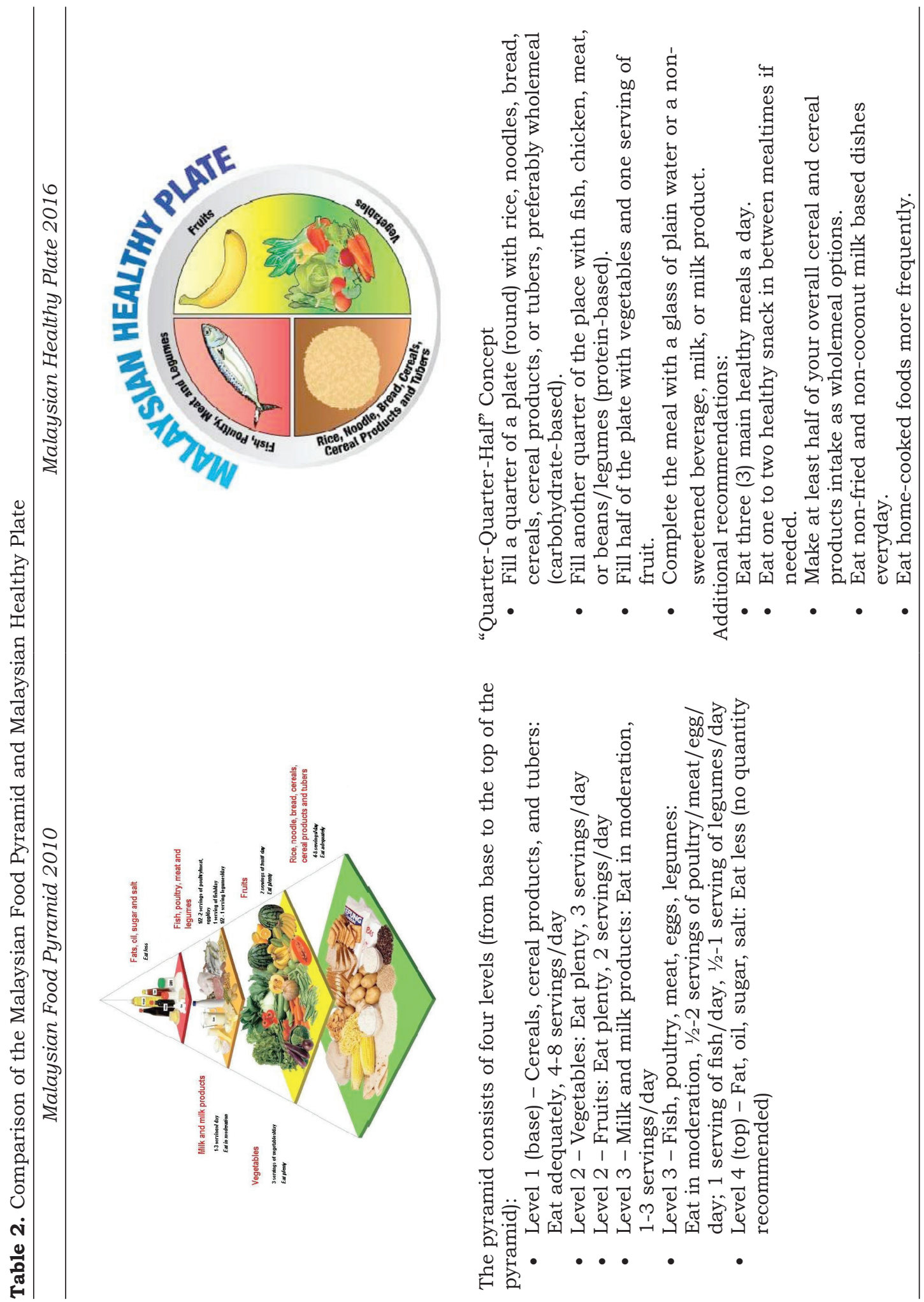




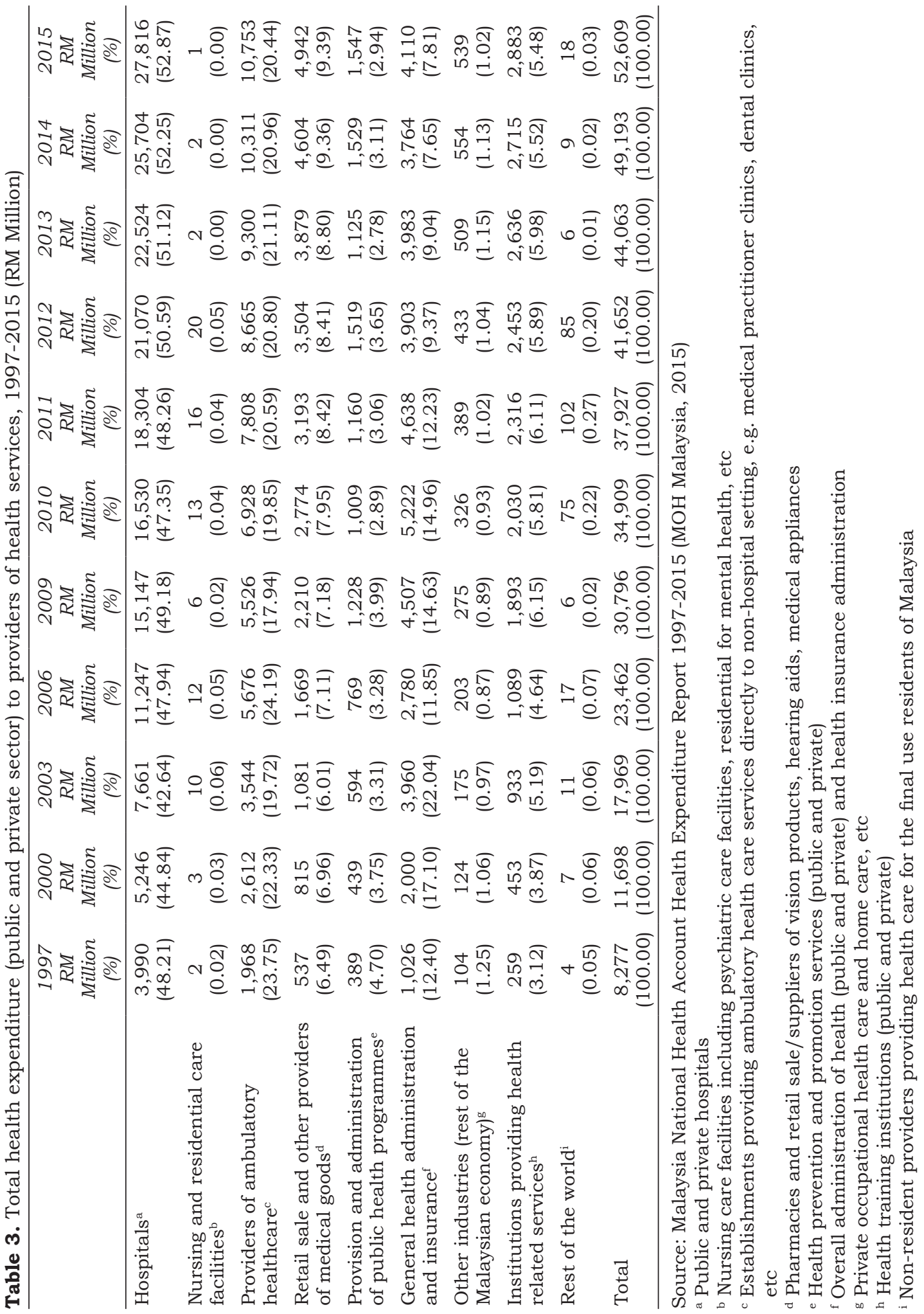




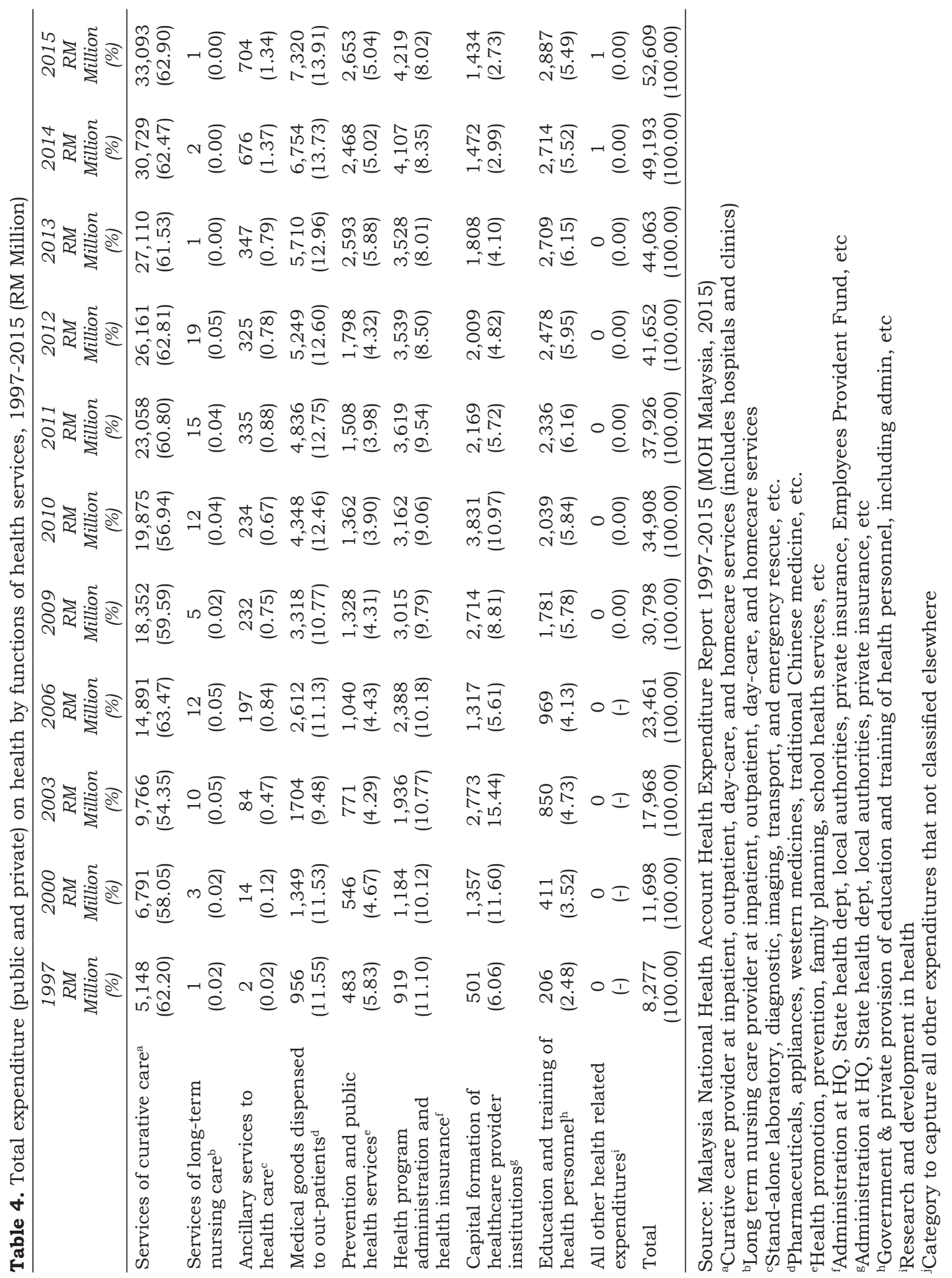


The Malaysian Healthy Plate was heavily promoted to the public through mass media, with a message of sukusuku-separuh (translated as "quarterquarter-half"), referring to fractions of a typical plate: one quarter for meat or fish (protein-based foods), one quarter for grains or carbohydrate-based foods, and half for vegetables and a serving of fruit. The healthy plate concept is highly visual and relatable, and thus easier to understand and put into practice than the more abstract food pyramid.

\section{Public health spending in Malaysia}

One way to improve the visibility and impact of public health messages is to increase expenditures. While specific data on the spending on public health nutrition messages and the costs of nutrition-related diseases are difficult to access, evidence from other sources suggest that Malaysia spends far more on treatments than on prevention. For example, according to the providers of healthcare services in Malaysia from 1997 to 2015, expenditures on hospitals, ambulatory health care, medicines, and medical appliances greatly exceeded the expenditure on health prevention and promotion services (Table 3). Indeed, expenditure on hospital treatments amounted to $50 \%$ or more of the total health expenditures (including public and private sectors), while $<5 \%$ was spent on the provision and administration of public health programmes. Over the same period, similar trends were seen for total health expenditure by the function of health services (Table 4). About 55$65 \%$ of expenditure was for services of curative care, whereas just 4-6\% was spent on prevention and public health services (Jackson \& Shiell, 2017).

While these figures would seem to indicate a low level of public health spending in Malaysia, they are actually considered to be fairly high with respect to the average share of total healthcare spending directed to prevention services in the Organisation for Economic Co- operation and Development (OECD) countries, where in most cases $<3 \%$. Indeed, health expenditure data must be interpreted with caution. For one, these data measure only expenditures by the health agencies, excluding spending by other agencies or other actors that may promote public health. For another, public health spending feeds into the systemic causes of health and is likely to have non-linear effects. For example, greater spending on public health promotion, including dietary messages, is likely to extend life expectancy. As such, individuals encountering the medical system may be older on average, with ailments that are more expensive to treat. Thus, high expenditures on treatment could potentially be indicative either of under-spending on prevention, or of a highly efficient system of prevention. More careful analysis of this issue in the Malaysian context would be valuable.

\section{Evolution and controversy in dietary guidelines}

Nutritional and dietary guidelines have evolved significantly over the past century, in parallel with greater understanding of the pathophysiological underpinnings of ill health. Modern nutritional science began with a strong focus on single-nutrient deficiencies and a concern over food shortages (Mozaffarian \& Forouhi, 2018). The isolation of Vitamin $\mathrm{C}$ as a cure for scurvy in 1932 was followed by the identification of other single-nutrient deficits related with health issues, such as Vitamin A deficiency with night blindness, Vitamin $\mathrm{D}$ with rickets, thiamine with beriberi, and niacin with pellagra (Mozaffarian $\&$ Forouhi, 2018). These relatively simple successes inspired a reductionist approach to nutritional science, in which the relevant nutrient for a given disease was identified and its target intake was established (Messina et al., 2001). This information was translated into simple messages for public consumption. 
As such, diseases were progressively eradicated through advances in nutritional science and improvements in farming and food production. However, other issues began to gain in prominence. Perhaps unsurprisingly, the reductionist approach that had previously been so successful was applied to these issues. This was readily seen in the 1980 United States Dietary Guidelines (USDA, 1980), in which the public was instructed to avoid fats (including saturated fat and cholesterol), which received the lion's share of the blame for heart disease and obesity epidemics. Guidelines for dietary fat were first introduced by the United States and United Kingdom Governments with the aim of reducing the prevalence of coronary heart disease. Despite a lack of evidence from randomised controlled trials to support such guidelines, they have prevailed for 40 years (Harcombe et al., 2015). The Malaysian Dietary Guidelines closely followed the United States guidelines, limiting the intake of foods high in fats and minimising the use of fats and oils in cooking. The Malaysian Food Pyramid also recommends reducing the intakes of fat, oils, sugar, and salt, although exact quantities are not mentioned. In the meantime, the 1980s saw an accelerating increase in obesity and overweight in the United States and other industrialised nations, and the emergence of chronic diseases related to overnutrition (Mozaffarian, 2017).

Clinicians are now questioning these existing food guidelines, which, in addition to adopting a reductionist perspective that now seems inadequate, are over-reliant on observational studies and small-scale, short-term interventions. Such studies are susceptible to confounding factors and errors in self-reported dietary assessments, and thus have questionable relevance to the real world (Mozaffarian $\&$ Forouhi, 2018). One major shift in nutritional thinking has been with respect to the role of fat. Indeed, there is evidence that restricting total fat intake leads to higher carbohydrate intake, resulting in increases in obesity and diabetes (Harcombe, Baker \& Davies, 2017). In a systematic review and metaanalysis across low-, middle-, and highincome countries, Sartorius et al. (2018) concluded that a high-carbohydrate diet, or an increased percentage of total energy intake in the form of carbohydrates, correspondingly increased the odds of obesity. While current opinions are not unanimous, this and numerous other findings question the prevailing assumptions and messages on good dietary practices. Such scientific debate over complex nutritional issues is inevitable and ought to produce better knowledge over time. However, it has also contributed to an ever-changing set of dietary recommendations, in which a nutrient is labelled harmful at one point in time, then healthy, then harmful again, causing public confusion and scepticism about scientific claims regarding nutrition (Mozaffarian, 2017). This confusion has been compounded by the accumulation of increasingly complex and nuanced findings which are more difficult to communicate than previous issues around single-nutrient deficiencies.

The controversial role of the food industry in public health dietary messages

Dietary guidelines from governments and advocacy organisations, themselves often muddled, compete with messages from other sources that ends up misinforming and confusing the public. In some cases, the food industry exacerbates this situation, including through promotion of unhealthy products, misleading marketing campaigns, targeting of children and other susceptible groups, corporate lobbying, co-opting of organisations and social media through financial support, and attacks against science and scientists. This may cause increasing distrust towards health 
professionals and reluctance among the public to accept public health messages (Crossley, 2002).

One prominent example of the influence of the food industry is the aggressive food marketing tactics used to promote junk food consumption among children. For instance, in 2012, the United States's fast food restaurant industry spent $\$ 4.6$ billion on advertising, while combined advertising on socalled "healthier" foods, including milk (\$169 million), bottled water (i.e., as an alternative to soft drinks) (\$81 million), vegetables ( $\$ 72$ million) and fruit $(\$ 45$ million), was less than one-twelfth that total (Harris et al., 2013). An average child in the United States watches about 4,700 food-related advertisements per year, of which $84 \%$ are about junk foods (Harris et al., 2015). Equivalent data on food marketing in Malaysia are not available at present, but it seems likely that unhealthy food advertising is equally predominant, if not more so, in this context. While powerful food companies have begun to be criticised and regulated in wealthier nations, lessdeveloped countries remain vulnerable, often lacking junk food marketing policies, in part because they do not have the financial wherewithal to combat the well-resourced food industry. Lessdeveloped countries also generally have a higher fraction of young people, who are more vulnerable to aggressive marketing tactics, and will therefore see higher undesirable impacts on them (Kovic et al., 2018).

Another conspicuous example involves sugar-sweetened beverages (SSBs), a top contributor to overall sugar consumption (Baker \& Friel, 2014). SSB consumption has been reported to be associated with increased waist circumference and other cardiometabolic risk factors, independent of physical activity levels and dietary patterns (Loh et al., 2017). However, in industrysponsored research on the health effects of SSBs (Bes-Rastrollo et al., 2013) and artificial sweeteners (Mandrioli, Kearns \& Bero, 2016), the likelihood of research conclusions being favourable to the sponsor is higher than in nonindustry-sponsored studies. Children and adolescents are frequent targets of SSB marketing strategies. This is critical because taste preferences are formed during youth and adolescence, and habitual exposure to SSBs can lead to unhealthy lifetime dietary habits (Gostin, 2018). Indeed, Brownell and Warner (2009) found that the food industry purposefully target youth populations to lock in new generations of consumers, a strategy previously adopted with much success by the tobacco companies.

Even when the food industry promotes healthier foods, it is usually done in ways that rely on reductionist messages that are easy to grasp, and that promise to improve health regardless of dietary and lifestyle context. The boom in the vitamin and dietary-supplement industry also relies on such marketing, despite a lack of evidence that these products benefit the general population (Jenkins et al., 2018). Similarly, the benefits of other so-called health foods and diets, including juices and gluten-free diets, have frequently been overstated and taken out of their context of the original research (Freeman et al., 2017). Such messages are further reinforced by dietary advices presented in the media, often based on the weakest forms of evidence, and therefore contributing to public misconceptions about food and health (Cooper et al., 2012).

\section{Cross-sector approaches in improving public health dietary messages}

To develop effective messages to combat obesity, it is necessary first to understand the systemic factors that give rise to obesity. Public health research, recommendations, and interventions relating to overweight and obesity prevention and treatments are often based on a simple energy balance model which neglects the complex physiological, 
behavioural and environmental systems that are involved (Hafekost et al., 2013). Human physiology is evolutionarily adapted to food-scarce environments and is regulated at several levels by complex, multiple feedback mechanisms that homeostatically regulate energy balance to maintain body weight, making weight loss difficult (Flier, 2017). One example of such regulatory mechanisms is the effect of calorie restrictions on resting metabolic rate, which decreases energy expenditure in response to reduced energy input (Martin et al., 2011; Martin et al., 2007). Even when weight loss is achieved, the compensatory physiological mechanism responses to perceive food scarcity during dieting, which then encourages weight gain up to a year later. These physiological adaptations may be poorly suited to modern human habitats that promote high energy intake and low energy expenditure, characterised by "an essentially unlimited supply of convenient, relatively inexpensive, highly palatable, energy-dense foods", combined with lifestyles that require only minimal levels of physical activity for survival (Hill \& Peters, 1998; Peters, 2003; Cohen, 2008). For this reason, Hill and Peters (1998) remarked that the culprit in the increasing prevalence of obesity is the environment that promotes obesity-causing behaviours. Since we are unable to change our physiology, it is the obesogenic environment that must be "cured" to stop and reverse the obesity epidemic (Hill \& Peters, 1998). Indeed, while poor dietary habits and inadequate physical activity are known contributing factors to the development of obesity and many NCDs (Booth, Roberts \& Laye, 2012; Lachat et al., 2013), public health professionals generally agree that genetic, biological, and psychological changes at the individual level are insufficient to explain the rapid modern rise in obesity rates. Therefore, the obesity epidemic must originate in a broader environmental, societal, and policy context (Koplan et al., 2005;
Novak \& Brownell, 2012; Kumanyika, Libman \& Garcia, 2013). A systems perspective, capable of recognising the shape and potential impacts of feedback mechanisms, is required to navigate these issues.

It is important to consider how health messages feed into the physiologicalenvironmental system that underlies obesity and the conditions necessary for information to be effective in this context. Public health messages aimed at reducing obesity must transcend an implied information-deficit model which assumes that supplying basic knowledge on nutrition is enough to achieve change. Rather, such messages are best understood as attempts to convince a very broad, diverse audience to make behavioural and lifestyle changes that are both difficult and at odds with their contextual cues and incentives. This differs from traditional marketing, which delivers uncomplicated, attractive messages to targeted audiences, and it should be no surprise that health messages achieve lower response rates (Kelly \& Barker, 2016). This problem is compounded when health sector messages compete against those from commercial food and "health" industries. The latter promote simpler products while also generating profits, allowing the private sector to far outspend the health sector in this context. At present, guidelines for health promotion focus on communication techniques, such as limiting the number of ideas to avoid confusing readers (US Department of Health and Human Services, 2006), reducing jargon and technical language, using active voice and conversational style, and providing concrete examples (Wigington, 2008). Indeed, beyond failing to enable healthier behaviours, poorly crafted messages may contribute to negative self-perceptions and, in the process, generate more pervasive problems (Penney \& Kirk, 2015; Rudoplh \& Hilbert, 2017). Yet, despite its importance, such techniques do not 
address the broad range of obstacles in the messaging environment.

Because knowledge is necessary, but not sufficient, to change behaviour (Worsley, 2002; Patton, 2008), messages targeted at individual behaviour need to be accompanied by strategies that create contexts where people are encouraged or naturally predisposed to act on these messages. Therefore, health communicators also need to consider how to influence the key actors who shape these environments. For example, the failure of town and transport planners to consider health issues in, for instance, the design of parks, recreation centres, and other public spaces has been seen as a cause towards the rise in the prevalences of obesity, NCDs, and sedentary behaviour (WHO, 2004). A wide range of stakeholders, both public and private, at the federal, state, and municipal levels, must play a role in halting the obesity crisis. Physical, social and cultural environments associated with work (Schulte et al., 2007; Hyun \& Kim, 2018), food (Mattes \& Foster, 2014; Steeves, Martins \& Gittelsohn, 2014), family (González Jiménez et al., 2012; Huang et al., 2017) and community (Yoon \& Kwon, 2014) can all enable and constrain individual choices and behaviours that affect obesity. For example, in Malaysia, the widespread practice of serving sweet and savoury snacks at morning and afternoon tea during functions, conferences and meetings enables over-consumption of foods, which also cements frequent eating as a social norm. Working hours (Cheong et al., 2010), availability of fast food (Abdullah et al., 2015), and school nutrition (SCHEMA, 2018), among other factors, also play key enabling/ constraining roles in Malaysia. Health messages and other policy interventions must target these physical, social and cultural environments, connecting actors and creating new feedback links to reshape systems in ways that promote health.
Within Malaysia there is such heterogeneity in the sociocultural environments that both the messages and the way they are communicated must be tailored to the local contexts, highlighting the importance of placebased thinking. Indeed, rates of obesity in Malaysia vary by geographical locations and ethnicity (IPH, 2015), and these differences are greater than can be explained by simple urban/ rural differentiation. Varied diets and cultures (Nurul Fadhilah, Teo \& Foo, 2016; Lee, 2017) imply that the changes needed to achieve healthy and sociallyacceptable eating habits and lifestyles may be very different for different ethnic and social groups. Similarly, identifying the appropriate form of messages and messengers for a target group is important and requires local knowledge (WHO, 2017). Acquiring and using this knowledge depends on early and consistent community engagement and participation in both research and policy processes, before problems and potential solutions are formulated (Bodison et al., 2015). Accounting for the particularities of place will better allow for the development of targeted and tailored messages, programmes, guidelines, and interventions to meet age, gender, culture, socioeconomic, and geographical needs.

\section{Recommendations for improving public health dietary messages in Malaysia}

To make dietary health messages in Malaysia a more effective vehicle for change, we suggest three broad strategic actions: building capacity and receptivity for complex ideas, mobilising a diversity of messengers, and implementing key policy interventions that target the food environment.

\section{Creating receptivity for complex ideas}

While health messages should be simple to enhance communication, many important dietary messages are 
inherently complex. In keeping with the systems view of public health dietary messages outlined above, various actions could be taken to improve the efficacy of messages in Malaysia without making them simplistic. First, an ability to understand complex messages needs to be developed within the community. Reductionist thinking continues to dominate science curricula, shaping the types of evidence people expect to see and are receptive to. Systems thinking, complexity, and holistic approaches to problem-solving could be introduced in school science curricula, for example in relation to biology, metabolism and nutrition (Fardet \& Rock, 2014). In the long term, exposure to these concepts can create an ability to understand the interconnected concepts necessary to address present and future nutrition challenges. While rewriting basic curricula will take years, if not decades, the cost of nutrition-related diseases, to say nothing of other complexity-related societal challenges, warrants such an effort. A body of evidence suggests that such concepts can be understood by lay people, practitioners, and students, when given the appropriate pedagogy (SCHEMA, 2018; Newell \& Siri, 2016). Second, it is still necessary to simplify complex messages, without making them simplistic, to meet existing capacities for comprehension. The Malaysia Healthy Plate is a good example of such translation. Further successes will depend in part on the involvement of local community leaders and members, as called for in NPANM III.

\section{Mobilising diverse messengers through a multi-sector approach}

As food is deeply tied to a wide range of social and cultural values, a multi-sector approach that addresses diet from a broader set of perspectives could increase effectiveness of dietary messages. While the $\mathrm{MOH}$ has actively fought overweight and obesity, gaps remain and these could be filled in by other ministries which have historically been less engaged on this issue, but whose activities and responsibilities have consequences for urban health. These would include the Ministries of Urban Well-being, Housing and Local Government; Education; Finance; Transport; Women, Family and Community Development; Agriculture and Agro-Based Industry; and Youth and Sports. Many of these government ministries have access to different community organisations, and their contacts could be used to deliver messages and implement interventions specific to the target communities. A good example is the KOSPEN programme, a collaboration between the $\mathrm{MOH}$ and the Ministry of Rural Development to recruit and mobilise community health volunteers (MOH Malaysia, 2016).

The food industry is a key player in shaping the food environment and has often (though not always) done so in ways that undermine health messages. Indeed, the United States Centers for Disease Control and Prevention (CDC) acknowledges that the food industry's "expertise, reach, and innovation can help address challenges in food production, formulation, and distribution; facilitate greater innovation for public good; and build capacity" despite the potential for bias (CDC, 2018). Nevertheless, partnerships between the health sector and the food industry must be governed by clear principles to avoid actions and perceptions that would compromise health promotion goals (Mozaffarian, 2017; CDC, 2018; Freedhoff \& Hébert, 2011).

The Malaysian health sector should also consider how to engage with the so-called public health activists "influencers", celebrity nutritionists, politicians, and food bloggers, to name a few, to encourage them to use messages based on best available evidence. These influencers have the potential to shape societal paradigms and purchasing choices, thus influencing and changing industry practices (Sbicca, 2012; Byrne, 
Kearney \& MacEvilly, 2017; Johnstone \& Lindh, 2018).

\section{Complementing messages with regulatory and fiscal policy}

Regulation is an important mechanism for shaping the nutrition information environment to catalyse desired behaviours. Yet, ensuring the accuracy and credibility of messages can be challenging. A 2010 WHO resolution, endorsed by 192 United Nations member states, urged the regulation of food and beverage marketing to children to address the childhood obesity epidemic (WHO, 2010). However, many countries rely on the food industry's self-regulation in marketing (Hawkes \& Lobstein, 2011). Malaysia, for example, has implemented food advertising regulations such as banning fast-food advertisements on children's television programmes, yet the Malaysian $\mathrm{MOH}$ has also endorsed self-regulation in the food industry. A prominent example is the Malaysian Food Manufacturing Group's "Responsible Advertising to Children - Malaysia Pledge" (Food Industry Asia, 2012; Food Industry Asia, 2013), the effects of which have not been studied. In some cases, the source of funding for nutritional research is likely to create conflicts of interest. For example, the $\mathrm{MOH}$ endorsed a popular malt drink, produced by a large multi-national company and marketed as a nutritious "Healthier Choice" made headlines in 2018, when a national controversy erupted over this drink's sugar content (Thiagarajan, 2018). Simultaneously, it came to light that the company in question also funds substantial nutrition research in Malaysia. This research included a study claiming correlations between consumption of malt drinks, physical activity and micronutrient intake among Malaysian children (Hamid et al., 2015). Such findings may be legitimate; for example, there might be cultural factors in this population associated with both malt-drink consumption and physical activity that explain the observed correlations. Nevertheless, results like this raise suspicion of conflicts of interest when there are perceived as lacking in transparency or external accountability (Mozaffarian, 2017). Indeed, such situations can also create suspicion of otherwise non-controversial results. Advertising regulations and $\mathrm{MOH}$ endorsements must be seen to be based on reliable and unbiased research to maintain the credibility of health promotion information.

Subsidies and taxes can also reinforce or subvert health messages and the capacity of the target audience to act upon them. They must be considered in the local economic and political context. For example, the WHO recommends restricting sugar consumption to $<10 \%$ of total energy intake, and advocates a further reduction to $<5 \%$ (WHO, 2015). Yet, sugar consumption worldwide exceeds these levels. Indeed, the Malaysian per-capita sugar consumption is among the highest in the world (1119 tsp/day) (Swarna Nantha, 2014; Amarra, Khor \& Chan, 2016), which is approximately $9-15 \%$ of total energy intake, (assuming it is 2000kcal/day). One response has been to tax products with high sugar content, such as SSBs, and this has been effective in some contexts (Colchero et al., 2017; WHO, 2017; Gostin, 2018). Yet, in Malaysia, the price of sugar is perceived to broadly affect food prices, making it an important political issue on a wider scale. In fact, sugar was subsidised until 2013, and Malaysia still maintains a price ceiling on sugar, with politicians continuing to advocate subsidies (Anon, 2017) or lowering of this ceiling (Ganeshwaran, 2018). At the same time, SSB taxes have been studied by $\mathrm{MOH}$ in the past, and have been proposed again recently in response to the rising diabetes rates 
(Anon, 2018). The contrasting positions on sugar prices and SSB taxes highlight the conflicting priorities between the trade and health arms of the Malaysian Government, illustrating the need for coordinated policies and mainstreaming of health in all government actions.

Subsidies can provide an effective complement to taxation in promoting better nutrition. Although white rice is culturally far more popular, perceived as finer and more desirable, but high consumption of white rice has been shown to increase type II diabetes risk, particularly in Asian populations (Hu et al., 2012). So, in neighbouring Singapore, the Health Promotion Board has coupled messages on the consumption of brown rice and other whole grains with subsidises for these staple ingredients in the food service industry (Singapore Health Promotion Board, 2018). As brown rice carries a higher price tag, in part due to the economies of scale, thus this subsidy attempts to shift private sector practices to reinforce the health messages on rice consumption. Such strategies are worth exploring in Malaysia, where many consumers have high price-sensitivity, and the direct cost of diabetes alone is estimated at RM 2.04 billion annually (Feisul Idzwan et al., 2017).

\section{CONCLUSION}

Being overweight or obese increases the risk of many health problems and imposes significant economic and social costs on the society. The alarmingly high prevalence of overweight and obesity in Malaysia thus represents a serious threat, not only to the health of its citizens, but to achieving other societal aspirations, including the United Nations Sustainable Development Goals (United Nations, 2015). This article reviewed public health dietary messages and guidelines connected to overweight and obesity issues, and examined gaps in some of these messages. Although public health dietary communication in Malaysia has progressed and improved substantially over the years, most messages have been designed for the general audience, with little consideration of differences in physical, social, cultural, and environmental backgrounds, and varying levels of comprehension. Such messages also compete with promotional information disseminated by profit-making food and "health" industries. We suggest that cross-sector approaches grounded in an appreciation of local context can offer solutions to make dietary health messages more effective, in particular by increasing understanding of the complex determinants of obesity, taking advantage of the systemic roles of multisector stakeholders, and implementing specific policy interventions that target the Malaysian food, social-cultural, and environmental contexts.

\section{List of abbreviations}

CDC, United States Centers for Disease Control and Prevention; MANS, Malaysian Adults Nutrition Survey; NCDs, Non-communicable diseases; $\mathrm{MOH}$, Ministry of Health; NHMS, National Health and Morbidity Survey; NPANM, National Plan of Action for Nutrition of Malaysia; SSBs, Sugar-sweetened beverages; USDA, United States Department of Agriculture; WHO, World Health Organization

\section{Acknowledgements}

This work was led by the United Nations University International Institute for Global Health and Cardiff University's Sustainable Places Research Institute. This work was funded by the British Council's Newton-Ungku Omar Institutional Links Fund via the SCHEMA project (Ref: 216400607).

\section{Authors' contributions}

All authors contributed to the paper and approved the final draft of the manuscript.

\section{Conflict of interest}

The authors declare that they have no conflicts of interest. 


\section{References}

Abdullah NN, Mazlin MM, Mohd Harriszamani AB \& Al-Kubaisy W (2015). Trend on fast food consumption in relation to obesity among Selangor urban community. Procedia - Social and Behavioral Sciences, ASLI QoL2014 (Annual Serial Landmark International Conference on Quality of Life) / AQoL 2014 Istanbul (ABRA International Conference on Quality of Life) (August):505-13. https://doi. org/10.1016/j.sbspro.2015.08.189

Amarra MSV, Khor GL \& Chan P (2016). Intake of added sugar in malaysia: a review. Asia Pac $J$ Clin Nutr 25(2):227-40.

Anon (2017). Selangor PKR Youth Wants Sugar Subsidy Restored. In: Malay Mail. March 3, 2017. From https://www.malaymail. com/s/1327357/selangor-pkr-youth-wantssugar-subsidy-returned [Retrieved November $12018]$.

Anon (2018). Govt Considering Soda Tax to Encourage Healthy Living, Says PM. In Malay Mail. August 27, 2018. From https://www. malaymail.com/s/1666339/govt-consideringsoda-tax-to-encourage-healthy-living-pm-says [Retrieved November 1 2018].

ARoFIIN (2016). Tackling Obesity in ASEAN: Prevalence, Impact and Guidance on Interventions. The Economist Intelligence Unit (EIU) and the Asia Roundtable on Food Innovation for Improved Nutrition (ARoFIIN). From https://www.eiu.com/public/topical report.aspx?campaignid=ObesityInASEAN [Retrieved June 1 2018].

Azmi MY, Junidah R, Siti Mariam A, Safiah MY, Fatimah S, Norimah AK, Poh BK, Kandiah M, Zalilah MS, Wan Abdul Manan W, Siti Haslinda MD \& Tahir A (2009). Body mass index (BMI) of adults: findings of the Malaysian Adult Nutrition Survey (MANS). Mal J Nutr 15(2):97119.

Baker P \& Friel S (2014). Processed foods and the nutrition transition: evidence from Asia. Obes Rev 15(7):564-77. https://doi.org/10.1111/ obr. 12174

Beaglehole R, Bonita R, Horton R, Adams C, Alleyne G, Asaria P, Baugh V, Bekedam H, Billo N, Casswell S, Cecchini M, Colagiuri R, Colagiuri S, Collins T, Ebrahim S, Engelgau M, Galea G, Gaziano T, Geneau R, Haines A, Hospedales J, Jha P, Keeling A, Leeder S, Lincoln P, McKee M, Mackay J, Magnusson R, Moodie R, Mwatsama M, Nishtar S, Norrving B, Patterson D, Piot P, Ralston J, Rani M, Reddy KS, Sassi F, Sheron N, Stuckler D, Suh I, Torode J, Varghese C \& Watt J (2011). Priority actions for the non-communicable disease crisis. Lancet 377(9775):1438-1447. https:// doi.org/10.1016/S0140-6736(11)60393-0

Bes-Rastrollo M, Schulze MB, Ruiz-Canela M \& Martinez-Gonzalez MA (2013). Financial Conflicts of Interest and Reporting Bias Regarding the Association between SugarSweetened Beverages and Weight Gain: A Systematic Review of Systematic Reviews. PLoS Medicine 10(12). https://doi.org/10.1371/ journal.pmed.1001578

Bodison SC, Sankaré I, Anaya H, BookerVaughns J, Miller A, Williams P, Norris K \& Community Engagement Workgroup (2015). Engaging the community in the dissemination, implementation, and improvement of healthrelated research. Clin Transl Sci 8(6):814-19. https://doi.org/10.1111/cts. 12342

Booth FW, Roberts CK \& Laye MJ (2012). Lack of exercise is a major cause of chronic diseases. Compr Physiol 2(2):1143-1211. https://doi. org/10.1002/cphy.c110025

Brownell KD \& Warner KE (2009). The perils of ignoring history: big tobacco played dirty and millions died. how similar is big food? The Milbank Quarterly 87(1):259-94. https://doi. org/10.1111/j.1468-0009.2009.00555.x

Byrne E, Kearney J \& MacEvilly C (2017). The role of influencer marketing and social influencers in public health. Proceedings of the Nutrition Society 76 (OCE3). https://doi.org/10.1017/ S0029665117001768

CDC (2018). CDC's Guiding Principles for PublicPrivate Partnerships: A Tool to Support Engagement with the Private Sector to Achieve Public Health. US Centers for Disease Control and Prevention, USA.

Cheong SM, Mirnalini K, Karuthan C, Chan YM \& Hazizi AS (2010). Prevalence of obesity and factors associated with it in a worksite setting in Malaysia. J Community Health 35(6):698705. https://doi.org/10.1007/s10900-0109274-1

Cohen DA (2008). Obesity and the built environment: changes in environmental cues cause energy imbalances. Int $J$ Obes 32(Suppl 7):S137-142. https://doi.org/10.1038/ ijo. 2008.250

Colchero M, Juan Rivera-Dommarco A, Popkin BM \& Ng SW (2017). In Mexico, evidence of sustained consumer response two years after implementing a sugar-sweetened beverage tax. Health Affairs 36(3):564-571. https://doi. org/10.1377/hlthaff.2016.1231 
Cooper BEJ, Lee WE, Goldacre BM \& Sanders TAB (2012). The quality of the evidence for dietary advice given in UK national newspapers. Public Underst Sci 21(6):664-673. https://doi. org/10.1177/0963662511401782

Crossley ML (2002). Resistance to health promotion: a preliminary comparative investigation of British and Australian students. Health Educ 102(6):289-299. https://doi. org/10.1108/09654280210446838

Fardet A \& Rock E (2014). Toward a new philosophy of preventive nutrition: from a reductionist to a holistic paradigm to improve nutritional recommendations. Adv Nutr 5(4):430-446. https://doi.org/10.3945/an.114.006122

Feisul Idzwan M, Soraya A, Mohd Rizal AM, Zanariah H, Nik Jasmin NM, Fatanah I, Azimatun NA \& Goh A (2017). What are the direct medical costs of managing type 2 diabetes mellitus in Malaysia? Med J Malaysia 72(5):7.

Flier JS (2017). What fuels fat. Sci Am 297(3):72-81. https://doi.org/10.1038/ scientificamerican0907-72

Food Industry Asia (2012). In: Government and Industry Come Together to Tackle NCDs. From https://foodindustry.asia/governmentand-industry-come-together-to-tackle-ncds [Retrieved 8 March 2018].

Food Industry Asia (2013). In: Malaysia Launches First Responsible Advertising to Children Pledge. From https://foodindustry.asia/malaysialaunches-first-responsible-advertising-tochildren-pledge [Retrieved 8 March 2018].

Freedhoff Y \& Hébert PC (2011). Partnerships between health organizations and the food industry risk derailing public health nutrition. Can Med Assoc J 183(3):291-292. https://doi. org/10.1503/cmaj.110085

Freeman AM, Morris PB, Barnard N, Esselstyn CB, Ros E, Agatston A, Devries S, O'Keefe $\mathrm{J}$, Miller M, Ornish D, Williams K \& KrisEtherton P (2017). Trending cardiovascular nutrition controversies. $J$ Am Coll Cardiol 69(9):1172-1187. https://doi.org/10.1016/j. jacc. 2016.10 .086

Ganeshwaran K (2018). Pakatan Govt May Lower Ceiling Price of Refined Sugar. In Business News The Star Online. From https:// www.thestar.com.my/business/businessnews / 2018/05/25/price-review-may-affectmsm/ [Retrieved 24 October 2018].
González Jiménez E, Aguilar Cordero MJ, García García CJ, García López P, Álvarez Ferre J, Padilla López CA \& Ocete Hita E (2012). Influence of family environment of the development of obesity and overweight in a population of school children in Granada (Spain). Nutr Hosp 27(1):177-184.

Gostin LO (2018). Tackling obesity and disease: the culprit is sugar; the response is legal regulation. Hastings Cent Rep 48(1):5-7. https://doi.org/10.1002/hast.804

Hafekost K, Lawrence D, Mitrou F, O'Sullivan TA $\&$ Zubrick SR (2013). Tackling overweight and obesity: does the public health message match the science? BMC Medicine 11(1):41. https:// doi.org/10.1186/1741-7015-11-41

Hamid JJM, Loy SL, Mohd Nasir MT, Norimah AK, Tan SY, Appukutty M, Nurliyana AR, Thielecke F, Hopkins S, Ong MK, Ning C \& Tee ES (2015). Characteristics associated with the consumption of malted drinks among Malaysian primary school children: findings from the MyBreakfast study. BMC Public Health 15:1322. https://doi.org/10.1186/ s12889-015-2666-5

Harcombe Z, Baker JS, Cooper SM, Davies B, Sculthorpe N, DiNicolantonio JJ \& Grace F (2015). Evidence from Randomised Controlled Trials Did Not Support the Introduction of Dietary Fat Guidelines in 1977 and 1983: A Systematic Review and Meta-Analysis. Open Heart 2(1):e000196. https://doi.org/10.1136/ openhrt-2014-000196.

Harcombe Z, Baker JS \& Davies B (2017). Evidence from prospective cohort studies does not support current dietary fat guidelines: a systematic review and meta-Analysis. $\mathrm{Br} J$ Sports Med 51(24):1743-1749. https://doi. org/10.1136/bjsports-2016-096550

Harris JL, Schwartz MB, Munsell CR, Dembek C, Liu S, LoDolce M, Heard A, Fleming-Milici F \& Kidd B (2013). Fast Food FACTS 2013: Measuring Progress in Nutrition and Marketing to Children and Teens 128. Yale Rudd Center for Food Policy \& Obesity, Yale.

Harris JL, Shehan C, Gross R, Kumanyika S, Lassiter V, Ramirez AG \& Gallion K (2015). Rudd Report: Food Advertising Targeted to Hispanic and Black Youth: Contributing to Health Disparities. Storrs, CT: Rudd Center for Food Policy and Obesity, University of Connecticut. http://www. uconnruddcenter.org/files / Pdfs / 272-7\%20 \%20Rudd_Targeted\%20Marketing\%20Report_ Release_081115\%5B1\%5D.pdf. 
Hawkes C \& Lobstein T (2011). Regulating the commercial promotion of food to children: a survey of actions worldwide. Int $J$ Pediatr Obes 6(2):83-94. https://doi.org/10.3109/1747716 6.2010 .486836

Hill JO \& Peters JC (1998). Environmental contributions to the obesity epidemic. Science 280(5368):1371-74.

Hu EA, Pan A, Malik V \& Sun Q (2012). White rice consumption and risk of type 2 diabetes: meta-analysis and systematic review. BMJ 344 (March):e1454. https://doi.org/10.1136/bmj. e 1454

Huang H, Che Wan Jasimah WMR \& Jenatabadi HS (2017). Family environment and childhood obesity: a new framework with structural equation modeling. Int $J$ Environ Res Public Health 14 (2). https://doi.org/10.3390/ ijerph 14020181

Hyun HS \& Kim Y (2018). Associations between working environment and weight control efforts among workers with obesity in Korea. Int J Med Res 46(6):2307-2316. https://doi. org/ $10.1177 / 0300060518764212$

IPH (1996). Second National Health and Morbidity Survey (NHMS 2). Institute for Public Health, Ministry of Health, Kuala Lumpur.

IPH (2006). The Third National Health and Morbidity Survey (NHMS III). Institute for Public Health, Ministry of Health, Kuala Lumpur.

IPH (2015). National Health and Morbidity Survey 2015 (NHMS 2015). Vol. II: Non-Communicable Diseases, Risk Factors \& Other Health Problems. Institute for Public Health, Ministry of Health, Kuala Lumpur.

Jackson H \& Shiell A (2017). How Much Does Australia Spend and Is It Enough? Canberra: Foundation for Alcohol Research and Education, Australia.

Jenkins DJA, Spence JD, Giovannucci EL, Kim YI, Josse R, Vieth R, Mejia SB, Viguiliouk E, Nishi S, Sahye-Pudaruth S, Paquette M, Patel D, Mitchell S, Kavanagh M, Tsirakis T, Bachiri L, Maran A, Umatheva N, McKay T, Trinidad G, Bernstein D, Chowdhury A, Correa-Betanzo J, Del Principe G, Hajizadeh A, Jayaraman R, Jenkins A, Jenkins W, Kalaichandran R, Kirupaharan G, Manisekaran P, Qutta T, Shahid R, Silver A, Villegas C, White J, Kendall CWC, Pichika SC, Sievenpiper JL (2018). Supplemental vitamins and minerals for CVD prevention and treatment. $J$ Am Coll Cardiol 71(22):2570-2584. https://doi.org/10.1016/j. jacc. 2018.04 .020
Johnstone L \& Lindh C (2018). The sustainabilityage dilemma: a theory of (un)planned behaviour via influencers. J Consumer Behav 17(1):e127139. https://doi.org/10.1002/cb.1693

Kelly MP \& Barker M (2016). Why is changing health-related behaviour so difficult? Public Health 136 (July):109-116. https://doi. org/10.1016/j.puhe.2016.03.030

Koplan JP, Liverman CT, Kraak VI \& Committee on Prevention of Obesity in Children and Youth (2005). Preventing childhood obesity: health in the balance: executive summary. $J$ Acad Nutr Diet 105(1):131-138. https://doi. org/10.1016/j.jada.2004.11.023

Kovic Y, Noel JK, Ungemack JA \& Burleson JA (2018). The impact of junk food marketing regulations on food sales: an ecological study. Obes Rev 19(6):761-769. https://doi. org/10.1111/obr. 12678

Kumanyika S, Libman K \& Garcia A (2013). Strategic Action to Combat the Obesity Epidemic: Report of the Obesity Working Group 2013, 48. WISH Obesity Report, Qatar.

Lachat C, Otchere S, Roberfroid D, Abdulai A, Seret FMA, Milesevic J, Xuereb G, Candeias V \& Kolsteren P (2013). Diet and physical activity for the prevention of noncommunicable diseases in low- and middle-income countries: a systematic policy review. PLoS Medicine 10(6):e1001465. https://doi.org/10.1371/ journal.pmed.1001465

Lee RLM (2017). Malaysian identities and mélange food cultures. J Intercult Stud 38(2):139-154. https://doi.org/10.1080/07256868.2017.128 9907

Loh DA, Moy FM, Zaharan NL, Jalaludin MY \& Mohamed Z (2017). Sugar-sweetened beverage intake and its associations with cardiometabolic risks among adolescents. Pediatr Obes 12(1):e1-e5. https://doi. org/10.1111/ijpo. 12108

Mandrioli D, Kearns CE \& Bero LA (2016). Relationship between research outcomes and risk of bias, study sponsorship, and author financial conflicts of interest in reviews of the effects of artificially sweetened beverages on weight outcomes: a systematic review of reviews. PLOS ONE 11 (9):e0162198. https:// doi.org/10.1371/journal.pone.0162198 
Martin CK, Das SK, Lindblad L, Racette SB, McCrory MA, Weiss EP, DeLany JP \& Kraus WE (2011). Effect of calorie restriction on the free-living physical activity levels of nonobese humans: results of three randomized trials. J Appl Physiol 110(4):956-963. https://doi. org/10.1152/japplphysiol.00846.2009

Martin CK, Heilbronn LK, de Jonge L, DeLany JP, Volaufova J, Anton SD, Redman LM, Smith SR $\&$ Ravussin E (2007). Effect of calorie restriction on resting metabolic rate and spontaneous physical activity. Obesity 15(12):2964-2973. https://doi.org/10.1038/oby.2007.354

Mattes R \& Foster GD (2014). Food environment and obesity. Obesity 22(12):2459-61.

Messina M, Lampe JW, Birt DF, Appel LJ, Pivonka E, Berry B \& Jacobs DR (2001). Reductionism and the narrowing nutrition perspective: time for reevaluation and emphasis on food synergy. J Am Diet Assoc 101 (12): 1416-1419. https:/ / doi.org/10.1016/S0002-8223(01)00342-X

MOH Malaysia (2015). Malaysia National Health Accounts: Health expenditure report 19972015. Ministry of Health, Putrajaya.

MOH Malaysia (2016). National Strategic Plan for Non-Communicable Disease (NSPNCD) 20162025. Ministry of Health, Putrajaya.

Mozaffarian D \& Forouhi NG (2018). Dietary guidelines and health-is nutrition science up to the task? BMJ 360 (March):k822. https:// doi.org/10.1136/bmj.k822

Mozaffarian D (2017). Conflict of interest and the role of the food industry in nutrition research. JAMA 317(17):1755-1756. https://doi. org/10.1001/jama.2017.3456

NCCFN (1996). National Plan of Action for Nutrition of Malaysia 1996-2000. National Coordinating Committee on Food and Nutrition, Ministry of Health, Kuala Lumpur.

NCCFN (2006). National Plan of Action for Nutrition of Malaysia 2006-2015. National Coordinating Committee on Food and Nutrition, Ministry of Health, Kuala Lumpur.

NCCFN (2010). Malaysian Dietary Guidelines. National Coordinating Committee on Food and Nutrition, Ministry of Health, Kuala Lumpur.

NCCFN (2016). National Plan of Action for Nutrition of Malaysia 2016-2025. National Coordinating Committee on Food and Nutrition, Ministry of Health, Kuala Lumpur.
Newell B \& Siri J (2016). A role for low-order system dynamics models in urban health policy making. Environ Int 95: 93-97. https:// doi.org/10.1016/j.envint.2016.08.003

Ng M, Fleming T, Robinson M, Thomson B, Graetz N, Margono C, Mullany EC, Biryukov S, Abbafati C, Abera SF, Abraham JP, Abu-Rmeileh NME, Achoki T, AlBuhairan FS, Alemu ZA, Alfonso R, Ali MK, Ali R, Guzman NA...Murray CJL (2014). Global, regional, and national prevalence of overweight and obesity in children and adults during 1980-2013: a systematic analysis for the Global Burden of Disease Study 2013. The Lancet 384 (9945):766-781. https://doi. org/10.1016/S0140-6736(14)60460-8

Novak NL \& Brownell KD (2012). Role of policy and government in the obesity epidemic. Circulation 126(19):2345-52. https://doi.org/10.1161/ CIRCULATIONAHA. 111.037929

Nurul-Fadhilah A, Teo PS \& Foo LH (2016). Ethnic differences in the food intake patterns and its associated factors of adolescents in Kelantan, Malaysia. Nutrients 8(9). https:/ / doi. org/10.3390/nu8090551

Patton MQ (2008). Utilization-Focused Evaluation. SAGE Publications.

Penney TL \& Kirk SFL (2015). The health at every size paradigm and obesity: missing empirical evidence may help push the reframing obesity debate forward. Am J Public Health 105(5):e38-e42. https://doi.org/10.2105/ AJPH.2015.302552

Peters JC (2003). Combating obesity: challenges and choices. Obes Res 11(S10):7S-11S. https://doi.org/10.1038/oby.2003.220

Rudolph A \& Hilbert A (2017). The effects of obesity-related health messages on explicit and implicit weight bias. Front Psychol 7 (January). https://doi.org/ 10.3389/fpsyg.2016.02064

Sartorius K, Sartorius B, Madiba TE \& Stefan C (2018). Does high-carbohydrate intake lead to increased risk of obesity? a systematic review and meta-analysis. BMJ Open 8(2):e018449. https://doi.org/10.1136/ bmjopen-2017-018449

Sbicca J (2012). Growing food justice by planting an anti-oppression foundation: opportunities and obstacles for a budding social movement. Agr Hum Values 29(4):455-466. https://doi. org/ 10.1007/s10460-012-9363-0 
SCHEMA (2018). SCHEMA Case Studies: Applying Systems Thinking to Urban Health and Wellbeing. Edited by David Tan and José Siri. United Nations University International Institute for Global Health, Kuala Lumpur, Malaysia.

Schulte PA, Wagner GR, Ostry A, Blanciforti LA, Cutlip RG, Krajnak KM, Luster M, Munson AE, O'Callaghan JP, Parks CG, Simeonova PP \& Miller DB (2007). Work, obesity, and occupational safety and health. Am $J$ Public Health 97(3):428-436. https://doi. org/ 10.2105/AJPH.2006.086900

Singapore Health Promotion Board (2018). About the Healthier Ingredient Development Scheme. From https://www.hpb.gov.sg/healthy-living/ food-beverage/healthier-ingredient-schemes / about-the-healthier-ingredient-developmentscheme [Retrieved 29 October 2018].

Steeves A, Martins EPA \& Gittelsohn J (2014). Changing the food environment for obesity prevention: key gaps and future directions. Curr Obes Rep 3(4):451-458. https://doi. org/10.1007/s13679-014-0120-0

Swarna Nantha Y (2014). Addiction to sugar and its link to health morbidity: a primer for newer primary care and public health initiatives in Malaysia. $J$ Prim Care Community Health 5(4):263-270. https://doi. org/ $10.1177 / 2150131914536988$

Tee ES (2011). Development and promotion of Malaysian Dietary Guidelines. Asia Pac J Clin Nutr 20 (3):455-461.

Thiagarajan T (2018). In: Here's All You Need to Know About The Viral Milo Sugar Controversy - WORLD OF BUZZ. From https://www. worldofbuzz.com/heres-need-know-viral-milosugar-controversy/ [Retrieved 3 November 2018].

United Nations (2015). Transforming our World: The 2030 Agenda for Sustainable Development. From: https://sustainabledevelopment. un.org/post2015/transformingourworld/ publication

USDA (1980). Nutrition and Your Health: Dietary Guidelines for Americans. Home and Garden Bulletin 232. US Department of Agriculture, USA. https://health. gov / dietaryguidelines / 1980 thin.pdf? ga $=2.102197889 .1240267622 .1536058546-$ 1520023397.1536058546 .

USDA (1992). The Food Guide Pyramid. USDA Center for Nutrition Policy and Promotion. Home and Garden Bulletin 252:17.
US Department of Health and Human Services (2006). Quick Guide to Health Literacy. US Department of Health and Human Services, USA.

Wigington PS (2008). Clear messages for effective communication. J Environ Health 70(10):3.

WHO (2004). In: Global Strategy on Diet, Physical Activity, and Health. World Health Organization. From http://www.who.int/ dietphysicalactivity / strategy / eb 11344 / strategy_english_web.pdf [Retrieved 12 March 2018].

WHO (2010). Set of Recommendations on the Marketing of Foods and Non-Alcoholic Beverages to Children. World Health Organization. From http://apps.who.int/iris/bitstream/ handle/10665/44416/9789241500210_eng. pdf;jsessionid=1AF2D6B6E 1 DBDB2A94BDB 57361573D7F?sequence $=1$ [Retrieved 8 March 2018].

WHO (2015). WHO calls on countries to reduce sugars intake among adults and children. World Health Organization. From https://www.who. int/mediacentre/news/releases/2015/sugarguideline/en/ [Retrieved 12 March 2018].

WHO (2017). Taxes on Sugary Drinks: Why Do It? World Health Organization. From: http: / / apps.who.int/iris / bitstream / handle / 10665 / 260253 / WHO-NMH-PND16.5Rev.1-eng.pdf?sequence $=1$ [Retrieved 8 March 2018].

WHO (2017). WHO Strategic Communications Framework for Effective Communications. World Health Organization. From http://www.who. int/mediacentre/communication-framework. pdf [Retrieved 8 March 2018].

WHO (2018). In: Obesity and Overweight. World Health Organization.From http://www.who. int/news-room/fact-sheets / detail/obesityand-overweight [Retrieved 16 February 2018].

Worsley A (2002). Nutrition knowledge and food consumption: can nutrition knowledge change food behaviour? Asia Pac J Clin Nutr $11 \quad$ (s3):S579-S585. https://doi. org/10.1046/j.1440-6047.11.supp3.7.x

Yoon NH \& Kwon S (2014). The effects of community environmental factors on obesity among Korean adults: a multilevel analysis. Epidemiology and Health 36 (December). https://doi.org/10.4178/epih/e2014036 